\title{
豆乳・牛乳混合系からのレンネットによるカード形成とその熟成
}

\author{
渡邊容子 ${ }^{\S}$, 関口正勝 ${ }^{*}$, 松岡博厚** \\ 東京都立短期大学 \\ *川村短期大学 \\ **十文字学園女子大学
}

\section{Curd Formation by Rennet from Soymilk Combined with Bovine Milk and its Ripening}

\author{
Yoko Watanabe ${ }^{\S}$, Masakatsu Sekiguchi* and Hiroatsu Matsuoka** \\ Department of Food Science and Human Nutrition, Tokyo Metropolitan College, \\ 3-6-33 Azuma-cho, Akishima-shi, Tokyo 196-8540 \\ * Department of Home Economics, Kawamura College, 2-22-3 Mejiro, Toshima-ku, Tokyo 171-0031 \\ ** Division of Human Life, Jumonji Gakuen University, 2-1-28 Sugasawa, Niza-shi, Saitama, 352-8510
}

\begin{abstract}
This study was carried out on coagulation and curd formation of combined milk consisting of soymilk and bovine milk by the action of calf rennet. The coagulation time of combined milk by rennet delayed with higher ratios of soymilk to skim milk. The suitable coagulation time to form curd could be obtained by the adjustment of calcium chloride concentration in combined milk by the addition of calcium chloride solution to skim milk. Lactic fermentation also accelerated the coagulation of combined milk by rennet. The curd was prepared from combined milk (soymilk : bovine milk $=1: 1$ ) containing $5 \mathrm{mM}$ of added calcium chloride by rennet action together with lactic fermentation. The yield of curd and solid in curd were $20.7 \%$ and $68.7 \%$, respectively. Hardness, shear stress, gumminess, chewiness etc. of the curd were lower than those of soymilk curd and combined milk curd prepared by lactic fermentation treatment only. Scanning electron microscopic observation showed the curd had partially formed coagulates, aggregates of coagulates and large empty voids. In 3 week's curd ripened with Penicillium caseicolum, water soluble nitrogen ratio was approximately $40 \%$ and free glutamic acid content reached to $199 \mathrm{mg} / 100 \mathrm{~g}$. The ripened curd had good umami taste and palatable texture but showed off-flavor with soapy and tallowy flavors.
\end{abstract}

(Received Dec. 22, 2003 ; Accepted Jun. 4, 2004)

豆乳を乳酸発酵することによりカードを形成し,Penicillium caseicolum（以下 P. caseicolum）を熟成用ス夕ー ターとして用い, チーズ様食品, いわゆる大豆チーズの製 造を試み，熟成の内容について検討してきた1)〜4).しかし， 牛乳からのチーズに比し，香気に欠け，またカルシウム含 量が低い.これらの点を改良するために, 筆者らは豆乳と 牛乳の混合系から乳酸発酵により共沈力ードを得, カルシ ウム含量の高いカードが得られたことおよび風味が改善で きたことを報告しだ．牛乳タンパク質と大豆タンパク質 との混合系について研究がなされており ${ }^{6 / 7)}$, イミテーショ ンチーズの製造屯試みられている ${ }^{8)}$ またた, 牛乳を発酵さ せ，レンネットで凝固させたさいにカード中に大豆タンパ ク質がよ゙のように取り込まれるかについての研究もなされ

テ196-8540 東京都昭島市東町 3-6-33

* 个171-0031 東京都豊島区目白 2-22-3

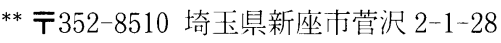

s連絡先 (Corresponding author), watanabe@tmca.ac.jp
ている ${ }^{9) \sim 11)}$. しかし，豆乳と牛乳の混合系からレンネット 凝固によりチーズ様食品の製造を試みた研究は少な (12113). そこで, 豆乳之牛乳の混合系から両タンパク質を 共沈させる方法の一つとして, 牛乳の凝乳酵素剂であるレ ンネットが利用できないかを検討し, 共沈の条件設定して カードを形成し P. caseicolumを用いて熟成を行い, 熟成 内容を調べたので報告する。

\section{実 験 方 法}

\section{1. 豆乳および脱脂乳の調製}

北海道産白目大豆鶴の子（100 g あたりの成分：水分 $11.8 \mathrm{~g}$, タンパク質 $35.6 \mathrm{~g}$, 灰分 $4.6 \mathrm{~g}$ ) 1 晚低温浸漬した のち, 10 倍加水豆乳 (100 g あたりの成分: 水分 $93.8 \mathrm{~g}$, 夕 ンパク質 $3.2 \mathrm{~g}$, 灰分 $0.4 \mathrm{~g}$ ，カルシウム $17 \mathrm{mg}$ ) を調製した. 脱脂乳は, 市販の脱脂粉乳 1 に対して所定濃度の塩化力 ルシウム溶液 9 の割合で混和・溶解したものを用いた。精 製水に溶解し得られた脱脂乳の $100 \mathrm{~g}$ あたりの成分は，水 
分 $89.6 \mathrm{~g}$, タンパク質 $3.4 \mathrm{~g}$, カルシウム $99 \mathrm{mg}$ であった.

\section{2. 配合乳の凝固について}

(1) 配合割合の違いによる凝固

豆乳上 $10 \mathrm{mM}$ 塩化カルシウム溶液に溶解した脱脂乳之 の比が $5: 0,4: 1,3: 2,1: 1,2: 3,1: 4$ および $0: 5$ に なるように配合乳を調製した。レンネット溶液は, Hansen 社製のレンネットを $100 \mathrm{mg} / 10 \mathrm{ml}$ になるように, 精製水に溶解したものを用いた。凝固試験は，従来法の肉 眼観察によるレンネットの牛乳凝固試験法に準じた ${ }^{14)}$ 。試 験温度は $30^{\circ} \mathrm{C}$ し, 赤く着色したガラス棒を用い, 肉眼で 細かい凝集物の生成が認められるに要した時間（分）を もって凝固速度として表した。

(2) 豆乳濃度の違いと凝固

豆乳は, 10 倍加水豆乳を原液とし, 精製水で 2 倍, 4 倍, 6 倍および 8 倍に豆乳濃度を希釈した豆乳を調製した。脱 脂乳は $20 \mathrm{mM}$ 塩化カルシウム溶液に溶解した。配合割合 は1：1とし，それぞれ調製した試料について凝固試験を 行った.

\section{(3) カルシウム量の違いによる凝固}

脱脂乳への添加塩化カルシウムの濃度は, 配合乳中の濃 度が 5〜25 mM になるように調製し，豆乳との配合比を 1:1の割合で混合したものについて，凝固試験を行った。

(4) レンネット添加量と凝固

脱脂乳は, $20 \mathrm{mM}$ 塩化カルシウム溶液で調製した。豆乳 $2.5 \mathrm{ml}$ と脱脂乳 $2.5 \mathrm{ml}$ を混合し，レンネットを $0.1,0.2$,

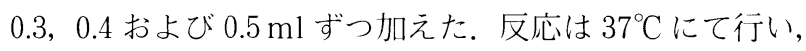
凝固時間を測定した。

\section{(5) 乳酸発酵による凝固}

脱脂乳は $15 \mathrm{mM}$ または $20 \mathrm{mM}$ 塩化カルシウム溶液で 調製したものを豆乳に対し $1: 1$ に混合した。脱脂乳培地

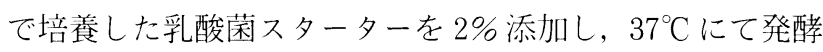
を行った。発酵中の乳酸酸度, $\mathrm{pH}$ および凝固時間を測定 した.

\section{（6）牛乳の殺菌条件の違いによる凝固}

試料は, 市販の低温殺菌乳（100 g あたりの成分：水分 $87.3 \mathrm{~g}$, タンパク質 $3.7 \mathrm{~g}$, 灰分 $0.7 \mathrm{~g}$, カルシウム $126 \mathrm{mg})$ および超高温殺菌乳を用いた。これらの牛乳試料は均質化 されたものであった。 カルシウム添加牛乳は，それぞれ添 加した塩化カルシウム濃度が $20 \mathrm{mM}$ になるよう調製し， 凝固試験を行った。

\section{3. 配合乳からのカードの製造}

豆乳と低温殺菌乳を 1:1の割合で ULTRA-TURRAX T25 (IKA 製) を用いて, $8000 \mathrm{rpm}, 2$ 分間覺找混和し, 配合乳を得た。この配合乳に添加塩化カルシウムの最終濃 度が $5 \mathrm{mM}$ になるように加えた。次に乳酸菌スターター Streptococcus salivarius subsp. thermophilus (以下 Stc. thermophilus）培養物を $3 \%$ 添加し， $37^{\circ} \mathrm{C}$ で発酵を行っ た。乳酸酸度が $0.16 〜 0.17 \%$ に達したときに凝固試験を行
い，10 分間で凝固するレンネット溶液量を加えた。凝固 後, カッティング・型詰め・圧搾を行いカードを得た。加 塩法によりP. caseicolum を接種し， $15^{\circ} \mathrm{C}$ で 3 週間熟成を 行った。

\section{4. 一般成分}

水分は常圧乾燥法, タンパク質はケルダール法によって 窒素を測定した。 タンパク質量は，カードについては大豆 のタンパク質換算係数 5.71 亡牛乳のタンパク質換算係数 6.38 加ら配合比 $1: 1$ に従って求めた 6.05 を乗じることに よって算出した. カードの脂質はクロロホルム・メタノー ル混液改良法 ${ }^{15)}$ にて測定した。 また, カルシウム量は, 試 料灰化後塩酸にて抽出を行い, 原子吸光法により测定し た. カードのフィチン酸の定量は, 既報 ${ }^{3)}$ に準じて行った.

\section{5. 水溶性窒素の測定}

カード試料の水溶性窒素の测定は, 既報 ${ }^{2)}$ に準じて行い, 熟成の指標として, 全跮素に対する水溶性窒素の比率を水 溶化率として表した。

\section{6. 遊離グルタミン酸}

遊離グルタミン酸は, 水溶性窒素試料から $75 \%$ エ夕 ノール抽出区分を調製し，このエ夕ノール抽出液中のグル 夕ミン酸量を酵素法 ${ }^{16)}$ ( $\mathrm{L}$-グルタミン酸測定用 $\mathrm{F}$ ーキット： Boehringer Mannheim 社製) により測定した。

\section{7. カードの物性}

テクスチュロメーター（全研，GTX-2 型）を用いて， カードの物性の測定を既報 ${ }^{17)}$ に準じて行った。なお，各試 料の検体数は 10 とし, 平均值を求めた。

\section{8. 走査型電子顕微鏡}

電子顕微鏡用試料調製および観察条件は，既報 ${ }^{17)}$ に準じ て行った。

\section{実 験 結 果}

\section{1. 配合乳の凝固について}

(1) レンネットによる凝固

亘乳と脱脂乳との配合割合が，レンネットによる凝固に およぼす影響について調べた結果を Table 1 に示す。脱脂 乳のみの配合比 $0: 5$ の試料は, 今回の実験条件下では約 3 分で凝固を示した。配合比 $1: 4$ の試料では凝固時間が約 7 分に延長された。しかし，これ以上豆乳の配合比が高くな ると $2: 3$ の試料であっても凝固に約 5 時間を要した。豆 乳の配合比が高い屯のはさらに長時間を要し, 豆乳のみの $5: 0$ おいては, 一晚放置後に凝固を示した。

\section{（2）豆乳濃度の違いと凝固}

配合乳中の豆乳濃度が高くなると, 凝固速度が極めて遅 くなることが観察された。この原因は，豆乳中にレンネッ 卜の凝固作用を阻害する物質が入っているためではないか と考えられる. Metwalli らも, 豆乳中にレンネットによる 凝固を阻害する成分の存在を示唆している ${ }^{12)}$. そこで豆乳 を2〜8 倍に希釈し， $20 \mathrm{mM}$ 塩化カルシウム溶液で溶かし 
Table 1 Effect of ratio of skim milk to soymilk in combined milk on coagulation time by action of calf rennet

\begin{tabular}{lccccccc}
\hline \hline & \multicolumn{7}{c}{ Soymilk: Skim milk } \\
& $5: 0$ & $4: 1$ & $3: 2$ & $1: 1$ & $2: 3$ & $1: 4$ & $0: 5$ \\
\hline Coagulation time & $\begin{array}{c}\text { over } \\
\text { night }\end{array}$ & $>5: 00^{\prime}$ & $>5: 00^{\prime}$ & $>5: 00^{\prime}$ & $5: 00^{\prime}$ & $7^{\prime} 02^{\prime \prime}$ & $3^{\prime} 05^{\prime \prime}$ \\
\hline
\end{tabular}

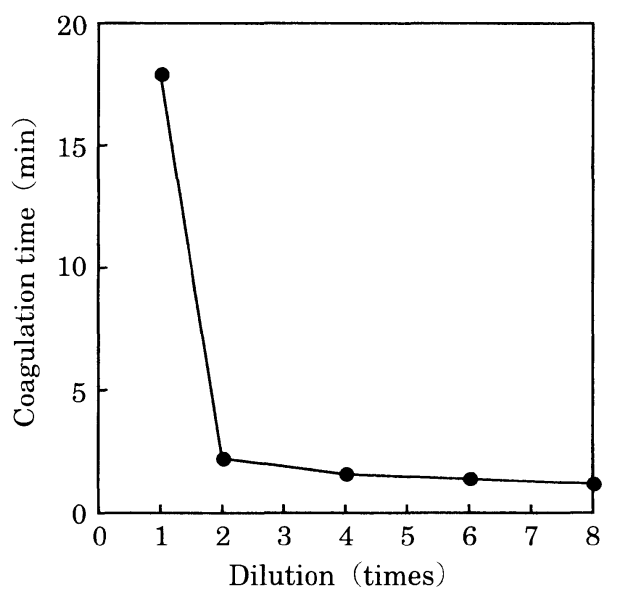

Fig. 1 Effect of dilution of soymilk on coagulation time of combined milk (soymilk : skim milk = $1: 1)$ with calf rennet as a coagulant

た脱脂乳と $1: 1$ に混合しレンネットの添加量を前記と同 様にした結果，Fig. 1にみられるように，1:1の希釈しな かった試料に打いても約 18 分で凝固を示した。一方, 豆乳 の濃度を 2 倍に希釈すると凝固時間は著しく短縮され, 約 2 分で凝固し，それ以上に希釈しても凝固時間は短縮され なかった。

本実験においては，前実験で 5 時間以上凝固を要した配 合比 $1: 1$ の試料でもわずか 18 分で凝固を示した。本実験 と前実験との違いは，本実験においては脱脂粉乳を溶解す るのに $20 \mathrm{mM}$ 塩化カルシウム溶液を用いたことである. これらの結果から明らかになったことは, 豆乳と脱脂乳之 を配合した乳を凝固させるためには, 一定量のカルシウム が必要であるということである. 脱脂乳に対する豆乳の比 が高くなるにつれ, 脱脂乳に含まれるカルシウムが豆乳に 含まれるフィチン酸と結合し，レンネット凝固においてカ ゼインを沈降させるためのカルシウム量が低下したため, 凝固時間が遅れたもの之考えられ，豆乳中に存在するレン ネットの阻害物質によるむのではないといえる.

(3) カルシウム量による凝固への影響

そこで次に豆乳と脱脂乳の配合比 $1: 1$ の配合乳を用い, カルシウム量との関係を検討した。予備試験の結果, 配合 乳に添加した塩化カルシウム濃度 $10 \mathrm{mM}$ 前後に最適カル シウム濃度があることが予想されたので, $10 \mathrm{mM}$ 付近を
中心に調べた. その結果, Table 2 にみられるように塩化 カルシウム濃度 $5 \mathrm{mM}$ では凝固はしなかったが， $7.5 \mathrm{mM}$ では 3.5 時間， $8.75 \mathrm{mM}$ 以降は濃度が高くなるにともない 凝固時間は急速に短縮され，20 $\mathrm{mM}$ および $25 \mathrm{mM}$ 溶液の 添加試料では，レンネットを添加せずに凝固することが認 められた。なお， $20 \mathrm{mM}$ 以下の塩化カルシウム濃度では， レンネット添加をしなければ，配合乳の凝固は 5 時間経過 しても認められなかった。

(4) レンネット添加量と凝固

次にレンネットの作用によって配合乳の凝固が起こった のかを確認するために，レンネットの添加量の影響につい て調べた. その結果, Fig. 2 にみられるように, 酵素量の 添加にともない凝固時間が直線的に短縮されることが認め られた。この結果は，配合乳の凝固にレンネット，すなわ ちキモシンの凝固作用が関与していることを示すものとい える.

（5）乳酸発酵による凝固への影響

配合乳にレンネットを加え凝固させる際に，乳酸菌ス ターターによる乳酸発酵を行い, 凝固への影響を調べた.

一般にチーズ製造においては，乳酸発酵をすることによっ て凝固時間が短縮される。

Table 3 にみられるように, 塩化カルシウム濃度 $10 \mathrm{mM}$ の配合乳においては, 未発酵の場合は約 3 分で凝固を示し たが，発酵 90 分後には 53 秒，120 分後には 35 秒と約 $1 / 6$ に短縮された。塩化カルシウム濃度 $7.5 \mathrm{mM}$ の試料では, 未発酵試料で凝固に要した時間は約 15 分をであったが, 乳酸発酵 120 分後には 1 分 33 秒之約 $1 / 10$ に短縮された。 これらのことは乳酸発酵之組み合わせた場合には, より低 濃度のカルシウム塩添加でレンネットの作用により配合乳 の凝固を起こさせることができることを示している.

（6）配合乳に用いる牛乳の殺菌条件による凝固への影響 豆乳之脱脂乳から成る配合乳で基本的な凝固条件を調心゙ たが，製品を作るさいには牛乳を使用するので，選択する 牛乳の殺菌条件が問題である。超高温殺菌乳ではレンネッ トによる凝固が起こりにくいことが知られている ${ }^{18)}$. Table 4 にみられるように豆乳上超高温殺菌乳, 低温殺菌 乳との 1:1の配合乳では, レンネット添加によっても凝 固しなかった。また，牛乳のみでも超高温殺菌乳は凝固し なかったが，低温殺菌乳では 16 分 38 秒で凝固を示した。

添加塩化カルシウム濃度を $20 \mathrm{mM}$ にした場合は, 配合乳 
Table 2 Effect of added calcium chloride concentration on coagulation time of combined milk (soymilk : skim milk = $1: 1$ ) by action of calf rennet

\begin{tabular}{|c|c|c|c|c|c|c|c|c|c|}
\hline & \multicolumn{9}{|c|}{$\mathrm{CaCl}_{2}$ concentration $(\mathrm{mM})$} \\
\hline & 5 & 7.5 & 8.75 & 10 & 11.3 & 12.5 & 15 & 20 & 25 \\
\hline Coagulation time & $\mathrm{NG}^{\mathrm{al}}$ & $3: 30^{\prime}$ & $10^{\prime} 03^{\prime \prime}$ & $5^{\prime} 16^{\prime \prime}$ & $2^{\prime} 10^{\prime \prime}$ & $0^{\prime} 16^{\prime \prime}$ & $0^{\prime} 10^{\prime \prime}$ & - b) & -b) \\
\hline
\end{tabular}

i) ; No coagulation after overnight.

b) ; Coagulated without addition of rennet solution.

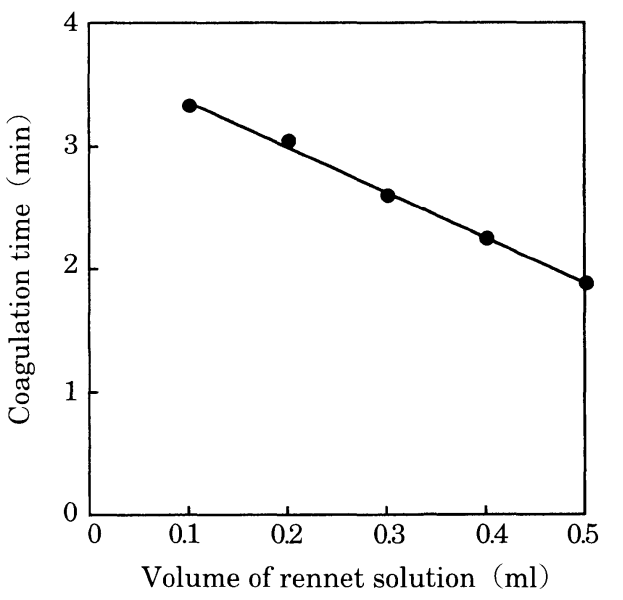

Fig. 2 Effect of the amount of calf rennet solution on coagulation time of combined milk (soymilk : skim milk $=1: 1$ )

では超高温殺菌乳で約 3 分, 低温殺菌乳では約 1 分で凝固 した。牛乳のみでは両牛乳之もこの $20 \mathrm{mM}$ 塩化カルシウム 濃度ではレンネットを添加せず凝固が起こった。これらの ことから, 超高温殺菌乳も配合乳の材料として使用可能で はあるが，今回はカルシウムの影響をより少なくすること を考え，低温殺菌乳を製造材料として用いることとした。

\section{2. カードの収量と一般成分}

前述の製造工程に従い，豆乳 $4900 \mathrm{~g}$ 之低温殺菌乳 4900 $\mathrm{g}$ を配合し, さらにスターター $294 \mathrm{~g}$ を加えて乳酸発酵し, レンネットを加えカードを作製した。その収量は $2090 \mathrm{~g}$, 配合乳（含スターター）に対する収率は $20.7 \%$, 固形分収 率は $68.7 \%$ であった。なお，このとき得られたホエーは, 透明であった。

配合乳力ード $100 \mathrm{~g}$ あたりの一般成分は, 水分 $69.1 \mathrm{~g}$, 夕 ンパク質 $14.0 \mathrm{~g}$, 脂質 $10.8 \mathrm{~g}$, 灰分 $0.9 \mathrm{~g}$, カルシウム 260 $\mathrm{mg}$ であった。

\section{3. カードの組織}

Table 5 にテクスチュロメーターで測定した配合乳カー ドの物性值を示した。また既報らで報告した豆乳カードお よび乳酸発酵配合乳カードの物性值を 100 としたときの割 合を示した。まず豆乳カードに対する物性值の割合で比較 してみると, 凝集性は約 70\%, 硬さは約 10\%, 剪断応力は
Table 3 Effect of lactic fermentation on coagulation time of combined milk (soymilk : skim milk $=1: 1)$ by action of calf rennet

\begin{tabular}{llcccc}
\hline \hline \multirow{2}{*}{$\begin{array}{l}\text { Add } \mathrm{CaCl}_{2} \\
\text { concentration }\end{array}$} & \multicolumn{4}{c}{ Fermentation time (min) } \\
\cline { 2 - 6 } & 0 & 90 & 120 & 150 \\
\hline $7.5 \mathrm{mM}$ pH & 6.44 & 6.37 & 6.30 & 6.12 \\
& Acidity (\%) & 0.147 & 0.176 & 0.170 & 0.183 \\
& Coagulation time & $14^{\prime} 41^{\prime \prime}$ & $5^{\prime} 35^{\prime \prime}$ & $1^{\prime} 33^{\prime \prime}$ & - $^{\mathrm{a}}$ \\
\hline \multirow{2}{*}{$10 \mathrm{mM}$} & 6.33 & 6.24 & 6.11 & 5.94 \\
& pH & 0.151 & 0.168 & 0.176 & 0.211 \\
& Acidity (\%) & $3^{\prime} 04^{\prime \prime}$ & $0^{\prime} 53^{\prime \prime}$ & $0^{\prime} 35^{\prime \prime}$ & - $^{\mathrm{a})}$ \\
\hline
\end{tabular}

a) ; Coagulated without addition of rennet solution.

Table 4 Coagulation of combined milk consisting of bovine milk and soymilk by action of calf rennet together with lactic fermentation

\begin{tabular}{|c|c|c|c|}
\hline \multirow{2}{*}{$\begin{array}{c}\text { Variety of } \\
\text { bovine milk }\end{array}$} & \multirow{2}{*}{$\begin{array}{c}\text { Added } \mathrm{CaCl}_{2} \\
\text { concentration } \\
(\mathrm{mM})\end{array}$} & \multicolumn{2}{|c|}{ Soymilk : Bovine milk } \\
\hline & & $1: 1$ & $0: 1$ \\
\hline \multirow{2}{*}{ LTLT } & 0 & $N G^{a \prime}$ & $16^{\prime} 38^{\prime \prime}$ \\
\hline & 20 & $1^{\prime} 03^{\prime \prime}$ & -b) \\
\hline \multirow[t]{2}{*}{ UHT } & 0 & $\mathrm{NG}$ & NG \\
\hline & 20 & $2^{\prime} 59^{\prime \prime}$ & _-bi \\
\hline
\end{tabular}

LTLT : low temperature long time pasteurization. UHT : ultra high temperature heating method.

a); No coagulation after overnight.

b) ; Coagulated without addition of rennet solution.

約 17\%, 弾力性は約 28\%, ガム性は約 7\%, 咀嚼性は約 $2 \%$ で, すべての物性において低い值を示した。一方, 乳酸 発酵配合乳カードで比較してみると，凝集性はほとんどか わらないが, 硬さは約 $12 \%$, 剪断応力は約 $33 \%$, 弾力性は 約 $28 \%$, ガム性は約 12\%, 咀嚼性は約 $3 \%$ と低い值を示し た。

\section{4. 電子顕微鏡}

Fig. 3 にみられるように, レンネット・カルシウム添 加, 乳酸発酵の組み合わせにより得られたカードは, 部分 的には凝集物が集まりカードを形成しているが，空陌が多 く，集合していない凝集物む多くみられた。これは，豆乳 と牛乳の配合比が 4 対 1 と今回用いた配合乳の豆乳と牛乳 
Table 5 Rheological values of curd prepared from combined milk by action of calf rennet with lactic fermentation

\begin{tabular}{lcrr}
\hline \hline & $\begin{array}{c}\text { Value } \\
(\text { T.U. })\end{array}$ & $\begin{array}{c}\text { Ratio }^{\text {al }} \\
(\%)\end{array}$ & $\begin{array}{c}\text { Ratio }^{\text {b) }} \\
(\%)\end{array}$ \\
\hline Cohesiveness & $0.40 \pm 0.04$ & 66.2 & 102.6 \\
Hardness & $0.040 \pm 0.004$ & 9.6 & 11.6 \\
Shear stress & $0.076 \pm 0.011$ & 16.9 & 33.3 \\
Springiness & $3.80 \pm 0.400$ & 27.8 & 28.0 \\
Gumminess & $1.60 \pm 0.286$ & 6.3 & 12.0 \\
Chewiness & $6.05 \pm 1.251$ & 1.8 & 3.4 \\
\hline
\end{tabular}

${ }^{a}$; Percentage of each rheological value of combined milk curd with rennet to that of soymilk curd by lactic fermentation ${ }^{51}$.

b) ; Percentage of each rheological value of combined milk curd with rennet to that of combined milk curd by lactic fermentation ${ }^{5}$.

Values given are means of ten trials in each sample.

の比率とは異なるが, 乳酸発酵のみで得られた配合乳力ー ドでは，凝集物がより緻密に集合し空隙も少なかっだりの に比し，明らかに異なった組織であった。

\section{5. カードの熟成}

P. caseicolum 接種後のカードタンパク質の水溶化率は Fig. 4 にみられるようにきわめて速く, 熟成 1 週目で約 $37 \%$ に達した。しかし，2 週目には約 $42 \%$ とこの間の水溶 化率の上昇は小さく, 熟成 3 週目にはやや減少する傾向に あった，熟成中の遊離グルタミン酸量は, 新鮮カードでは みられなかったが, 熟成 1 週目で試料 $100 \mathrm{~g}$ 当たり $55 \mathrm{mg}$ に増加し， 2 週目で $176 \mathrm{mg}, 3$ 週目には $199 \mathrm{mg}$ と熟成期 間中をとおして上昇した。 カードは熟成にともない旨味が 感じられ, 組織も軟らかく口触り屯よかったが, 脂肪の分 解に由来すると思われる石けん臭, 獣脂臭などのオフフ レーバーが強く感じられた。

\section{考 察}

豆乳と脱脂乳を混合し得た配合乳にレンネットを作用さ せた結果，脱脂乳に対する豆乳の割合が高くても，添加塩 化カルシウムの添加濃度を高くすることにより配合乳を凝 固させることができた。牛乳がレンネットにより凝固する のは，牛乳に仔在する安定なカゼインミセルがキモシンの 作用によりミセルを構成する ンとマクロペプチドに解離することにより, カゼインミセ ルを構成する主要タンパク質である $\alpha_{\mathrm{s} 1}$ カがイインと $\beta$ カガ インがКーカゼインによりカルシウムからの保護作用が失 われることによって, 本来のカルシウム感受性となり沈降 する．また，パラКーカゼインの疎水性が各タンパクの複合 体形成にも関与すると考えられる ${ }^{19)}$. チーズ製造において むレンネットを作用させカードを効率よく形成させるため

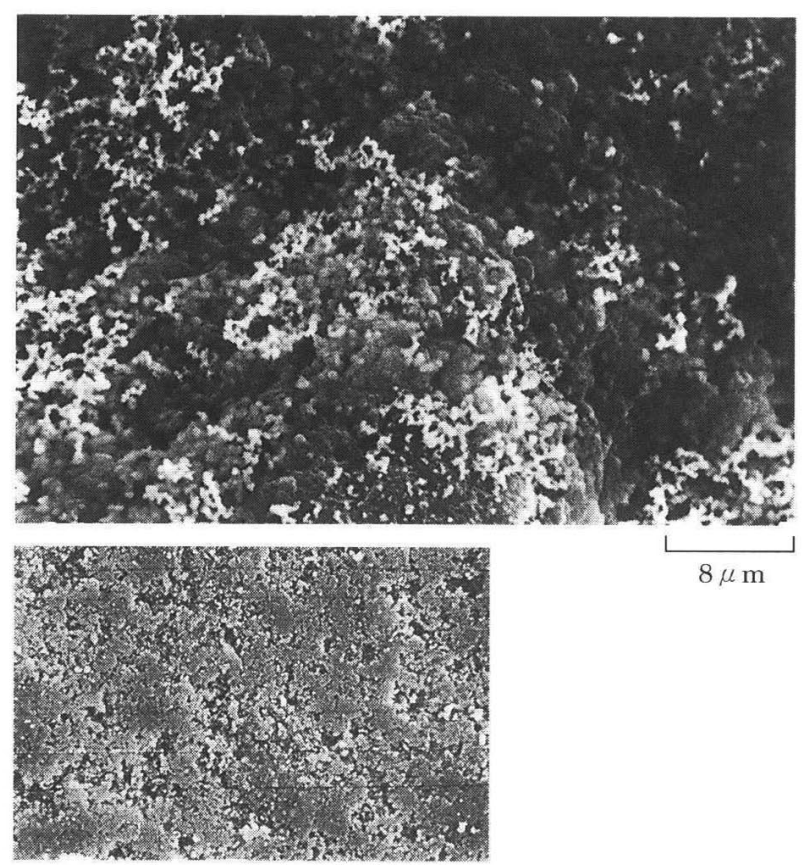

* Lactic fermentation curd

Fig. 3 A scanning electron micrograph of curd prepared from combined milk (soymilk : bovine milk $=1: 1$ )

${ }^{*}$ Micrograph of lactic fermentation curd was shown as a reference.

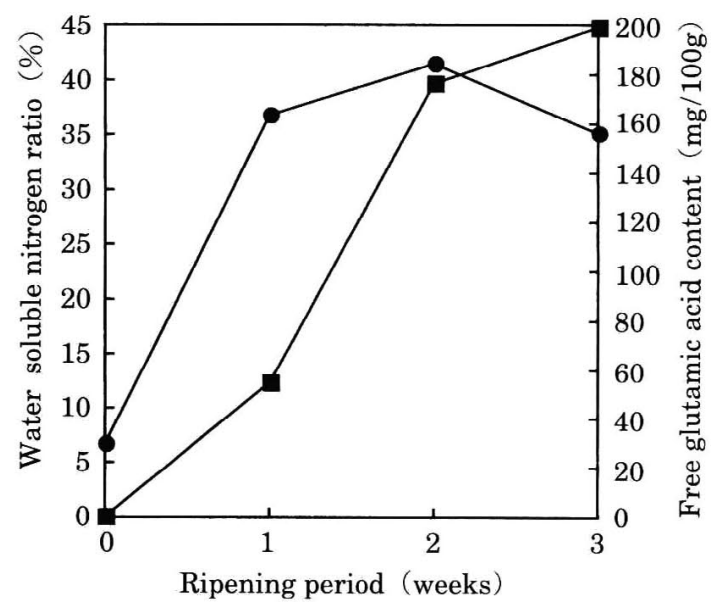

Fig. 4 Changes in water soluble nitrogen ratio to the total nitrogen and free glutamic acid content during ripening of curd prepared from combined milk (soymilk : bovine milk $=1: 1$ )

๑, water soluble nitrogen; $\mathbf{\square}$, free glutamic acid.

には, カルシウムが牛乳 $100 \mathrm{ml}$ 当たり $140 \sim 160 \mathrm{mg}$ 存在 するのがよく, 殺菌操作により不溶化したカルシウムを補 うために実際チーズ製造丁程では塩化カルシウムを $0.02 \%$ 位添加されている20). 牛乳中のカルシウムの存在形態は, 可溶性カルシウムと不溶性カルシウムに大別され, 可溶性 カルシウムは約 30\%の割合で存在している．この可溶性 
カルシウムは, イオン状カルシウム $\left(\mathrm{Ca}^{2+}\right)$ と非イオン状 カルシウム (りん酸塩, くえん酸塩など) に分けられ, 牛 乳の $\mathrm{Ca}^{2+}$ 濃度は約 $2.5 \mathrm{mM}(10 \mathrm{mg} / 1)$ で, 加熱処理によっ て減少し，わずかの量の $\mathrm{Ca}^{2+}$ の減少であレンネットによ る凝固時間が大幅に遅延することが知られている ${ }^{21)}$. チー ズ製造にさいし，レンネットによる凝固を効果的にするた めに添加された $0.02 \%$ 塩化カルシウムは, 牛乳の $\mathrm{Ca}^{2+}$ 濃 度を $2.0 \mathrm{mM}$ 高くすることになる. 本実験においても脱脂 粉乳の溶解に用いた塩化カルシウム濃度が配合乳のレン ネットによる凝固に影響し，一定量のカルシウム $\left(\mathrm{Ca}^{2+}\right)$ が必要なことが認められた。ささらに，配合乳のレンネット による凝固においては, 添加したカルシウムが豆乳に存在 するフィチン酸と結合し，凝固に影響することが考えられ る. 脱脂粉乳を $10 \mathrm{mM}$ 塩化カルシウム溶液に溶解した脱 脂乳のカルシウム濃度は $9 \mathrm{mM}$ であり, 豆乳のフィチン酸 含量は約 $0.160 \%(\text { 約 } 2.4 \mathrm{mM})^{3)}$ とすると, 豆乳と脱脂乳が 1:4の比率の配合乳に存在する添加カルシウム濃度は 7.2 $\mathrm{mM}$, フィチン酸は $0.48 \mathrm{mM}$ となる。フィン酸とカルシ ウムの結合については, フィチン酸とカルシウムのモル 比, $\mathrm{pH}$ などより違いがみられるが, モル比が $1: 5$ 以上 になるとフィチン酸カルシウムの沈殿が完全に生じると報 告されている222. また, $10 \mathrm{mM} \mathrm{Ca}^{2+}$ の存在下でフィチン 酸の濃度が 2 2.5 $\mathrm{mM}$ の付近で溶解度が最小になること 屯認めら机ている23!。 これらのことから，フィチン酸と力 ルシウムのみの系では条件によっては，1 モルのフィチン 酸に約 5 モルの $\mathrm{Ca}^{2}$ 結合することが考えられる.しかし， 豆乳中のフィチン酸の一部はカルシウム, マグネシウムと 結合したフィチン態として存在し，タンパク質との複合体 を形成していることも考えられ，豆乳中のフィチン酸が添 加 $\mathrm{Ca}^{2}$ ‘よどのような比で結合するかを予测することは難 しい，そこで，添加 $\mathrm{Ca}^{2}$-とフィチン酸の濃度を比率でみ てみると, 豆乳と $10 \mathrm{mM}$ 塩化カルシウムにて溶解した脱 脂乳の比が $1: 4$ の試料では, $15: 1(7.2 \mathrm{mM}: 0.48 \mathrm{mM})$ で あり，このときレンネットにより 7 分で凝固している。こ のように計算すると亘乳：脱脂乳の比が $2: 3$ の配合乳で は $5.6: 1$ ( $5.40 \mathrm{mM}: 0.97 \mathrm{mM})$ で凝固に要した時間は 5 時 間,さらに1: 1 の配合乳では, $3.7: 1$ (4.50 mM : 1.21 $\mathrm{mM})$ で 5 時間以上凝固に要した。一方, 豆乳と $20 \mathrm{mM}$ 塩 化カルシウム溶液を用いて調製した脱脂乳の比が $1: 1 の$ 配合乳では, $\mathrm{Ca}^{2}$ とフィチン酸の濃度比は $7.4: 19.00$ $\mathrm{mM}$ ：1.21 mM）となり 18 分でレンネットにより凝固を示 した。また， 2 倍希釈豆乳と脱脂乳が $1: 1$ の配合乳では， $15: 1$ (9.00 mM : 0.60 mM) となり, 凝固時間は 2 分之短 かった。配合比 $1: 1$ の試料を用いカルシウム濃度を变え た場合をみると, $5 \mathrm{mM}$ 塩化力ルシウム添加試料では, カル シウム：フィチン酸は $4.1: 1(5.0 \mathrm{mM}: 1.21 \mathrm{mM})$ でレン ネットによる凝固はみられなかった。添加力ルシウムが 7.5 $\mathrm{mM}$ のさいには $6.2: 1$ (7.5 mM : $1.21 \mathrm{mM})$ で凝固時間は 3
時間 30 分, $8.75 \mathrm{mM}$ のさいは, $7.2: 1$ (8.75 mM : $1.21 \mathrm{mM})$ で 10 分 3 秒, $10 \mathrm{mM}$ のさいは $8.3: 1 \quad(10 \mathrm{mM}: 1.21 \mathrm{mM})$ で 5 分 16 秒, また $15 \mathrm{mM}$ では $12.4: 1$ (15 mM: $1.21 \mathrm{mM})$, 10 秒で凝固を示した。これらから配合乳をレンネットで効 果的に凝固させるためには，フィチン酸に対するカルシウ ム濃度比が一定以上であることが必要と考えられる。ま た, カルシウム濃度が同じ条件である $20 \mathrm{mM}$ 塩化カルシ ウム溶液で諴製した脱脂乳之豆乳の配合比が $1: 1$ の試料 における凝固時間に比べ，豆乳を 2 倍希粎したものを用い た配合乳試料のほうが，レンネットによる凝固時間が短縮 されたことも，フィチン酸による影響があることを示して いるよいえる，先に記したように，豆乳に存在するフィチ ン酸が添加した $\mathrm{Ca}^{2+}$ とよ゙のように結合するかを推測する ことは難しいが, 配合乳からの乳酸発酵カードのカルシウ ム量とフィチン酸量の比が $3: 1$ であった5)ことなどを考 慮し, フィチン酸 1 モルが 3 モルの $\mathrm{Ca}^{2-}$ と結合したと仮 定すると，レンネットにより 7 分で凝固をした豆乳：脱脂 乳比が 1:40試料では遊離型の $\mathrm{Ca}^{2+}$ 濃度は $5.8 \mathrm{mM}$ とな る. 18 分で凝固した 1: 1 の場合は $5.4 \mathrm{mM}, 2$ 倍希釈豆乳 を用いたさいには $7.2 \mathrm{mM}, 2$ 分で凝固, 10 分で凝固した $8.75 \mathrm{mM}$ 添加試料では $5.1 \mathrm{mM}$ など， 10 分以内でレンネッ 卜を用いて配合乳を凝固させるには，遊離 $\mathrm{Ca}^{2}$ 濃度が 5 $\mathrm{mM}$ 以上であることが必要ではないかと考えられる。

$\alpha_{\mathrm{S1}_{1}}$ カゼインおよび $\beta$-カゼインは $1 \sim 3 \mathrm{mM}$ で会合し, $10 \mathrm{mM}$ で凝固するといわれている(19). またチーズ製造にお いて, レンネット添加後約 10 分で凝固させるのに牛乳の $\mathrm{Ca}^{2-}$ 濃度が約 $4.0 \mathrm{mM}$ がよいということと上記の結果は ほぼ一致しているといえる。

低温殺菌乳の場合をみると, 遊離型のカルシウム濃度は 約 $6 \mathrm{mM}$ になり, 凝固時間は 1 分 3 秒であり, 上記の例と 類似している. 超高温殺菌乳は一般にレンネット凝固しに くいとされ, その原因は加熱変性した $\beta$ ラクトグロブリン

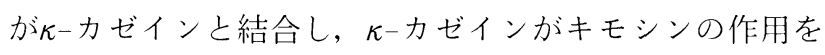
受けにくいためと考えられている18). 本実験においては, 超高温殺菌乳のみでは凝固を示さなかったが, 配合乳では 約 3 分間で凝固を示した。これは, 加熱变性した $\beta$ ラクト グロブリンが大豆タンパク質之結合し，K-カゼインとの 複合体形成を妨げたためと推察されるが，このことについ ては今後検討したいと考えている.

配合乳の凝固がレンネットの作用で誘導される結果が得 られた。 上記のようにレンネットにより凝固したカゼイン が，酸凝固の場合上同様にフィチン酸・カルシウム・大豆 タンパク質複合体と結合することによって, 配合乳の凝固 が起きたものと考えられるが，得られたカードの硬さは， 酸凝固のカードに比し柔らかく, また電子顕微鏡による組 織にも違いがみられたことからも，その凝固機構について はさらなる検討が必要之考えている.

カードは熟成によってタンパク分解は良好に進行し, 結 
果には示さなかったが, SDS-PAGEによりタンパク分解 を調べたところ, 熟成 2 3 週目には牛乳および豆乳タン パク質がともに良く分解することが認められた。しかし， 配合乳からの乳酸発酵カードとは異なり，熟成中にオフフ レーバーの生成がみられた。使用した乳酸菌スターター (Stc. thermophilus) とかびスターター（P. caseicolum）は 同じなのに，本実験におけるカードがオフフレーバーを生 じたのは，使用したレンネットに原因があると考えられ る。レンネットに混在しているリパーゼが配合乳に含まれ る乳脂肪・大豆油に作用し，加水分解した脂肪酸からの二 次的生産物によってオフフレーバーが生じたものと思われ る。本実験では子牛レンネットを用いたが，微生物レン ネットなどと比較し，この点を改善したいと考えている.

\section{要 約}

豆乳と牛乳の混合系がレンネットで共沈するかを調べ， 配合乳から乳酸発酵とレンネット併用によるカード形成を 行い, P. caseicolum を熟成用スターターに用い熟成し, 次 の結果を得た.

(1) 配合乳の豆乳の比率が高くなると，レンネットによ る凝固の速度は遅くなる傾向が認められた。

（2）豆乳濃度を希釈することにより，レンネットによる 凝固速度は速くなった。

（3）豆乳と脱脂乳の配合比が 1:1の配合乳を試料とし た場合, 添加塩化カルシウム濃度が高くなるにともないレ ンネットにより凝固時間が短縮され，10 $\mathrm{mM}$ では約 5 分 で凝固を示した。しかし，レンネット無添加では 5 時間経 過しても凝固はみられなかった。

(4) 配合乳のレンネットによる凝固は，レンネット添加 量が増すによもない，凝估時間が直線的に短縮された。

（5）脱脂乳の代わりに牛乳を用いた配合乳では，低温殺 菌乳および超高温殺菌乳を配合した配合乳ともにレンネッ トにより凝固し，カード形成された。また，配合乳を乳酸 発酵することにより凝固時間は著しく短縮された。

(6) 豆乳之牛乳の配合比が 1: 1 の配合乳を用いて乳酸 発酵・レンネット添加により得られたカードの物性は, 豆 乳カードおよび乳酸発酵配合乳カードに比べ硬さ，剪断応 力，ガム性および咀嚼性と屯低い值を示した。

（7）走査型電子顕微鏡観察によるとカードの組織は，部 分的には凝集物が集まりカードを形成しているが，空陌が 多く集合していない凝固物む多くみられた。

（8）熟成によるタンパク質の水溶化はきわめて早かっ た。また，カード中の遊離グルタミン酸量も熟成とともに 増加し, 旨みも感じられた。しかし, 脂肪の分解に由来す ると思われるオフフレーバーが強く感じられた。

\section{文献}

1）松岡博厚, 福家洋子, 乳酸発酵による大豆乳カードの形成
とその熟成，日食工誌，24，553-558（1977）。

2）福家洋子，松岡博厚，Penicillium caseicolum 在用いた大 豆乳からのチーズよう食品の熟成中に扒ける蛋毛質とブロ テアーゼ活性の変化，由食工誌，34，826-833（1987）.

3）渡邊容子, 松岡博厚, 大豆チーズ製造・熟成中のフィチン 酸の変化よPenicillium caseicolum のフィターゼ库生, 月 食工誌，41，627-632（1994）.

4）松岡博厚，ダイズチーズの製造法抢よび熟成機構，食科工， 42, 945-951 (1995).

5）渡邊容了, 関口正勝, 松岡博㫗, 宣乳・牛乳混合系加らの乳 酸発酵によるカード形成とその熟成，食科 I.，47，30-36（2000）。

6）青木 宏, 白瀬好子, 加藤潤子, 渡巡雄 よミルクカゼインの混命系が示す粘性抢よび乳化炎定性, 日食工誌，31，333-338（1984）.

7）青木 宏, 白瀬好子, 加藤潤子, 渡辺雄一, 大宁夕ンパク質 とミルク・カゼインの混命系が示す乳化穴定性一超名波乳 化を中心に，日食丁訫，33，167-170（1986）。

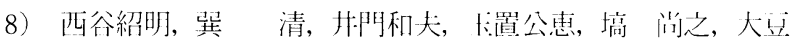
蚠白質とカゼインを混合したイミテーションモザレラチー ズの機能性について，门食L誌，36，805-811（1989）.

9）岡崎良生，鬼頭 誠，内海 成，牛乳カードへの大安タンバ 質の取り込み，食科 T，47，378-383（2000）。

10）岡崎良生，内海成，分離大豆夕ンバク質を含有する牛乳 カードにおけるタンパク質間相五.作用力，食科 T，47，808811 (2000)

11）岡崎良生, 内海 成, 人呈 $7 \mathrm{~S}$ 扰よび $11 \mathrm{~S}$ グロブリンを含有 する牛乳カードにおけるタンバク質間相互.作用ノ, 食科工, 48, 356-360 (2001).

12) Metwalli, N.H., Shalabi, S.I., Zahran, A.S. and ElDemerdash, O., The use of soybean milk in soft-cheese making: I. Effect of soybean milk on rennet coagulation property of milk. J. Food. Technol., 17, 71-77 (1982).

13) Metwalli, N.H., Shalabi, S.I., Zahran, A.S. and ElDemerdash, O., The use of soybean milk in softcheese making: II. Organoleptic and chemical properties of Domiati cheese made from a mixture of soybean milk and whole milk. J. Food. Technol., 17, 297-305 (1982).

14）津郷友吉, 山内邦男, 牛乳の变化, 「牛乳の化学」, 第 1 版 (地球社, 東京), pp. 178-188（1975)。

15）堤忠一，平田芳明，一般成分㧍よび関連成分，「新・食品分 析法」，第 1 版，日本食品科学:丁学全，新・食品分析法編集 委員会編， (光琳，東京), pp. 51-53 (1996).

16) Beutler, H.-O., In "Methods of enzymatic analysis", 3rd ed., Vol. VIII, Bergmeyer, H.U,. ed, pp. 369-376 (1985).

17）松岡博厚，関口正勝，ブロメライン処埋大要自質の加熱 凝固，日食工誌，39，316-321（1992）。

18）大谷 元，牛乳の貯蔵・加丁中に抢ける牛乳タンパク質の 変化,「タンパク質の科学」, 第 1 版, 鈴木敦上, 渡部終厉, 中川弘毅編, (朝合書店, 束宗), pp. 64-66（1998）。

19）下葉英雄，古川正明，タンパク質分子間の相后作用一カゼ

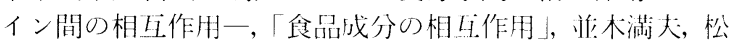
下雪郎編（講談社，東宗），pp. 100-115（1980）。

20）米田義樹，C. チーズ「ミルク総合稺典」, 第 1 版, 山川内邦琞, 横山健吉編，(朝倉書店，東京), pp. 206-232（1998）。

21）下野勝映, 下村正已, 牛乳の加熱变化, 特に蛋向質之カルシ ウムの変化について，乳技協資料，33，1-11（1983）。

22) Grynspan, F. and Cheryan, M., Calcium Phytate: Effect of $\mathrm{pH}$ and Molar Ratio on in vitro Solubility, JAOCS, 60, 1761-1764 (1983).

23) Graf, E., Chemistry and applications of phytic acid : an overview, 「Phytic acid $\rfloor$, (Pilatus Press, Minneapolis), pp. 1-21 (1986).

(平成 15 年 12 月 22 日受付，平成 16 年 6 月 4 日受理) 